\title{
EFEKTIVITAS GEL EKSTRAK ETANOL BAWANG PUTIH (Allium sativum L.) TERHADAP BAKTERI Staphylococcus aureus
}

\author{
Irene Puspita Dwei ${ }^{1}$, Ilham Maslan Orde ${ }^{2}$ Verawaty $^{3}$ \\ ${ }^{1,2,3}$ Akademi Farmasi Prayoga Padang \\ Email koresposdensi : irene.puspadewi@yahoo.com
}

\begin{abstract}
ABSTRAK
Bawang putih (Allium sativum L.) merupakan salah satu obat tradisional yang memiliki senyawa berkhasiat sebagai antibakteri yaitu Allisin yang mampu menghambat pertumbuhan bakteri Staphylococcus aureus. Penelitian ini bertujuan untuk memformulasi ekstrak umbi bawang putih menjadi sediaan gel yang baik untuk digunakan sebagai obat jerawat serta mengetahui efektifitas antibakteri pada gel ekstrak etanol bawang putih terhadap bakteri Staphylococcus aureus menggunakan metode sumuran. Evaluasi gel yang dilakukan memenuhi syarat dengan parameter uji organoleptik, homogenitas, $\mathrm{pH}$, daya sebar, daya lekat dan uji iritasi. Penelitian ini menggunakan ekstrak konsentrasi $10 \%$ dan 20\%, pada masing-masing konsentrasi mampu menghambat pertumbuhan bakteri Staphylococcus aureus. Pada formula konsentrasi $20 \%$ mempunyai diameter zona hambat sebesar $1,59 \mathrm{~cm}$ dan konsentrasi $10 \%$ mempunyai daya hambat $1,50 \mathrm{~cm}$. Hasil uji statistik menggunakan uji One Way ANOVA didapatkan bahwa tidak terdapat perbedaan yang bermakna antara rata-rata diameter daya hambat gel ekstrak bawang putih konsentrasi $10 \%$ dengan konsentrasi $20 \%$.
\end{abstract}

Kata kunci : Gel, Bawang putih (Allium sativum L.), Staphylococcus aureus, antibakteri. 


\title{
EFFECTIVENESS OF GARLIC (Allium sativum L.) ETHANOL EXTRACT ON BACTERIA Staphylococcus aureus
}

\begin{abstract}
Garlic (Allium sativum L.) is one of the traditional medicines which has an antibacterial efficacy compound namely Allisin which is able to inhibit the growth of Staphylococcus aureus bacteria. This study aims to formulate the garlic bulb extract into a good gel preparation for use as an acne drug and to determine the antibacterial effectiveness of the ethanol extract of garlic gel against the bacterium Staphylococcus aureus using the wells method. The gel evaluation was carried out to meet the requirements with organoleptic test parameters, homogeneity, pH, spreadability, adhesion and irritation test. This study uses extracts of $10 \%$ and $20 \%$ concentrations, at each concentration being able to inhibit the growth of Staphylococcus aureus bacteria. In the formula, the concentration of $20 \%$ has a inhibition zone diameter of $1.59 \mathrm{~cm}$ and a concentration of $10 \%$ has a inhibition of $1.50 \mathrm{~cm}$. Statistical test results using the One Way ANOVA test found that there was no significant difference between the average diameter of inhibition of garlic extract gel concentration of $10 \%$ with a concentration of $20 \%$.
\end{abstract}

Keywords : Gel, Garlic (Allium sativum L.), Staphylococcus aureus, antibacterial.

\section{PENDAHULUAN}

Bawang putih (Allium sativum L.) merupakan salah satu tanaman yang paling banyak digunakan masyarakat sebagai bumbu masakan. Selain menambah cita rasa, juga menambah aroma masakan menjadi lebih nikmat. Bawang putih tidak hanya digunakan sebagai bumbu masakan, ternyata juga baik untuk kesehatan dan mampu mengobati berbagai penyakit (Ross et al., 2001). Ada banyak khasiat dan manfaat dari bawang putih digunakan sebagai obat dalam seperti mengurangi kadar kolesterol dalam darah, mencegah serangan jantung, menstabilkan sistem pencernaan yang terganggu, meningkatkan daya tahan tubuh, mengobati nyeri sendi, menghambat penuaan sel otak, mengurangi gejala 106 diabetes melitus, asma dan lain sebagainya. Sebagai obat luar digunakan untuk mengobati jerawat, bisul, sakit gigi, infeksi jamur pada kaki, infeksi telinga, mengobati panu, kadas, kurap dan lain sebagainya (Bayan et al., 2014). Salah satu penyakit kulit yang sering dialami oleh masyarakat adalah jerawat (Acne vulgaris).

Acne vulgaris adalah suatu keadaan dimana pori-pori kulit tersumbat sehingga timbul bruntusan (bintik merah) dan abses (kantong nanah) yang meradang dan terinfeksi pada kulit. Jerawat sering terjadi pada kulit wajah, leher dan punggung baik laki-laki maupun perempuan (Sampelan et al., 2017). Penyebab acne vulgaris 
sangat banyak (multifaktorial), antara lain faktor genetik, faktor bangsa ras, faktor makanan, faktor iklim, faktor jenis kulit, faktor kebersihan, faktor penggunaan kosmetik, faktor stress, faktor infeksi dan faktor pekerjaan (Afriyanti, 2015).

Bakteri merupakan salah satu penyebab timbulnya gangguan pada kulit diantaranya adalah Staphylococcus aureus. Bakteri ini menyebabkan infeksi yang ditandai dengan kerusakan jaringan yang disertai abses bernanah. Beberapa penyakit infeksi yang disebabkan oleh Staphylococcus aureus adalah bisul, jerawat, impetigo, dan infeksi luka. (Myles \& Datta, 2012).

Tanaman bawang putih ini diduga mempunyai efek antibakteri, antiviral, antifungi, anti protozoa dan antiparasit yang membantu penyembuhan peradangan pada kulit akibat infeksi mikroorganisme (Salima, 2015). Bawang putih mempunyai senyawa aktif seperti sativin, alisin, alul sulfida, alil propil sulfida, alil vinil sulfida, dan garlisin (Prihandani et al., 2015). Zat yang berperan sebagai antibakteri dalam bawang putih adalah allicin (bersifat mudah menguap) dan kandungan organosulfur. Aktivitas antibakteri bawang putih dapat mengendalikan bakteri-bakteri patogen, baik gram positif maupun gram negatif (Iwalokun et al., 2004). Perlu dikembangkan alternatif bahan alam untuk mengatasi permasalahan tersebut, sediaan anti jerawat telah banyak beredar baik dalam bentuk gel, krim, dan losio. Peneliti ingin membuat sediaan ekstrak bawang putih dalam bentuk gel. Gel dipilih karena tidak mengandung minyak sehingga tidak akan memperburuk jerawat, bening, mudah mengering membentuk lapisan film yang mudah dicuci, juga bentuk sediaan gel cocok untuk terapi topikal pada jerawat terutama penderita dengan tipe kulit berminyak (Voigt, 1994).

Oleh sebab itu, peneliti tertarik ingin menguji efektivitas gel ekstrak zat antibakteri yang terdapat pada bawang putih terhadap Staphylococcus aureus menggunakan ekstrak etanol bawang putih dalam bentuk sediaan gel. Selain mudah digunakan, gel merupakan sediaan yang paling banyak digunakan untuk skincare pada jaman ini.

\section{METODE PENELITIAN MATERIAL}

Alat

Cawan petri, tabung reaksi, gelas ukur (Pyrex), erlenmeyer (Pyrex), pipet ukur (Pyrex), bola hisap, lumping dan alu, cawan penguap, autoklaf (My Life), ose, bunsen, jangka sorong (Tricle Brand), timbangan analitik (Kern Abs), oven (Memmert), rotary evaporator (Buchi) , inkubator, $\mathrm{pH}$ meter (Hanna Instruments), corong kaca, spatel, kertas saring, handscoon, kertas label, gunting, spidol, penggaris,

\section{Bahan}

Bawang putih, NA (Nutrient Agar), $\mathrm{NaCl}$ fisiologis, biakan bakteri Staphylococcus aureus (Lab. Mikrobiologi Universitas Andalas), HPMC (Hidroxy Propyl Methyl Cellullose), Propilen glikol, Klindamisin gel gel 1\%, aquadest.

\section{Rancangan Penelitian}

1) Pembuatan Ekstrak 
Bawang putih yang digunakan sebanyak 650 gr yang segar, tidak busuk dan serta beraroma khas. Bawang putih terlebih dahulu dikupas kulitnya dan dicuci dengan air mengalir hingga bersih, lalu tiriskan. Kemudian bawang putih diiris halus dan dimaserasi dengan etanol 96\% hingga semua umbi bawang putih terendam selama $1 \times 24$ jam. Bawang putih yang telah direndam dengan etanol kemudian disaring agar terpisah dari ampasnya. Proses tersebut diulangi 2 kali. Lalu filtratnya diambil dan kemudian diuapkan dengan rotary evaporator pada suhu $40^{\circ}-70^{\circ} \mathrm{C}$ hingga diperoleh ekstrak kental (Prihandani et al., 2015).

2) Pembuatan Sediaan Gel dari Ekstrak Etanol Umbi Bawang Putih Berikut adalah formula pembuatan gel (Anggraeni \& Kamaluddin, 2018)

Tabel 1. Formula Gel Ekstrak Etanol Umbi Bawang Putih

\begin{tabular}{ccc}
\hline \multirow{2}{*}{ Nama Bahan } & \multicolumn{2}{c}{ Formula } \\
\cline { 2 - 3 } & I & II \\
\hline Ekstrak etanol Umbi & $10 \%$ & $20 \%$ \\
Bawang Putih & $4 \%$ & $4 \%$ \\
HPMC & $10 \%$ & $10 \%$ \\
Propilen Glikol & Ad 50 & Ad 50 \\
Aquadest &
\end{tabular}

Cara kerja pembuatan sediaan gel dari ekstrak etanol umbi bawang putih adalah :

a. HPMC dikembangkan dengan menggunakan air panas $(20 \mathrm{x}$ bobot HPMC) lalu digerus hingga mengembang. Kemudian tambahkan propilen glikol gerus homogen. Lalu tambahkan aquadest sedikit demi sedikit, lalu gerus homogen hingga terbentuk basis gel.

b. Kemudian tambahkan basis gel kedalam ekstrak etanol umbi bawang putih kemudian gerus homogen.

c. Obat siap, lalu masukkan ke dalam wadah yang tertutup rapat dan simpan pada suhu kamar.

3) Penentuan Diameter Zona Hambat

Tuangkan $1 \mathrm{ml}$ suspensi bakteri ke dalam masing-masing 3 cawan petri steril selanjutnya tambahkan media NA $15 \mathrm{ml}$ ditutup dan dihomogenkan dengan cara menggoyangkan seperti angka delapan sebanyak 5 kali, lalu dibiarkan sampai membeku. Lalu buat lubang kecil di agar tiap-tiap cawan petri, lalu masukan masing-masing ekstrak etanol bawang putih (Allium sativum L.) $10 \% \mathrm{~b} / \mathrm{v}, 20 \% \mathrm{~b} / \mathrm{v}$, ke dalam lubang kecil, dan Klindamisin gel gel $1 \%$ (kontrol positif) dan basis gel (kontrol negatif) ke masing-masing agar cawan petri, lalu tutup seluruh cawan petri. Kemudian inkubasikan seluruh cawan petri dalam incubator dengan suhu $37^{\circ} \mathrm{C}$ selama 24 jam. Amati dan ukur daya hambat yang terjadi menggunakan jangka sorong pada masing-masing sampel (Ningsih et al., 2016). 
HASIL DAN PEMBAHASAN Hasil Evaluasi Fisik Sediaan Gel
Hasil evaluasi sediaan gel adalah sebagai

Tabel 1. Hasil Evaluasi Sediaan Gel

\begin{tabular}{ccc}
\hline \multirow{2}{*}{ Evaluasi gel } & \multicolumn{2}{c}{ Formula } \\
\cline { 2 - 3 } Bentuk & $10 \%$ & $20 \%$ \\
Warna & Kental & Kental \\
& & Kuning \\
& & kecoklatan \\
Bau & & pekat \\
Homogenitas & Khas bawang putih & Khas bawang \\
pH & Homogen & putih \\
Daya tercuci & 4,82 & Homogen \\
Uji iritasi & $15 \mathrm{~mL}$ & 5,14 \\
kulit & & $18 \mathrm{~mL}$ \\
& & Tidak \\
& & mengiritasi \\
\hline
\end{tabular}

Pada hasil evaluasi sediaan gel seperti yang tertera pada tabel 2, didapatkan hasil sediaan gel yang kental, dan berbau khas umbi bawang putih, semakin besar konsentrasi pada formula maka semakin pekat warna pada sediaan gel. Ini dikarenakan semakin banyaknya ekstrak umbi bawang putih dimasukan kedalam sediaan gel tersebut, sedangkan untuk uji evaluasi homogenitas diperoleh sediaan gel yang homogen. Pada uji daya tercuci terdapat perbedaan jumlah air yang digunakan untuk mencuci sediaan gel dari tiap konsentrasi sediaan gel, semakin besar konsentrasi sediaan gel maka semakin banyak jumlah air yang dibutuhkan untuk mencuci sediaan gel, hal ini disebabkan karena adanya zat warna yang terdapat pada ekstrak umbi bawang putih. Pada parameter $\mathrm{pH}$ terdapat perbedaan di tiap-tiap konsentrasi yaitu, semakin besar konsentrasi sediaan gel maka $\mathrm{pH}$ yang diperoleh juga semakin besar. $\mathrm{pH}$ sediaan terkait dengan keamanan konsumen saat pengaplikasian, sediaan gel harus sesuai $\mathrm{pH}$ fisiologis kulit yaitu 4,5 - 6,5 agar tidak mengiritasi kulit (Genaro, 1990).

Pada penelitian ini, perlakuan dibagi menjadi 5 kelompok, yaitu kelompok gel konsentrasi 10\%, kelompok gel konsentrasi 20\%, kelompok ekstrak bawang putih, kontrol negatif, dan kontrol positif. Kontrol negatif yang digunakan adalah basis gel, dengan tujuan melihat apakah basis gel yang digunakan memberikan daya hambat terhadap bakteri Staphylococcus aureus. Kontrol positif yang digunakan adalah Klindamisin gel karena Klindamisin gel merupakan antibiotika topikal efektif pada jerawat sehingga mampu membantu menghambat pertumbuhan bakteri (Harahap \& 
Marwali, 2000). Pemilihan Klindamisin gel gel $1 \%$ sebagai kontrol positif juga didasarkan kepada penelitian yang dilakukan oleh Luky Hayuning Les pada tahun 2020 (Les et al., 2017) dan Sarah Pelen pada tahun 2016 (Pelen et al., 2016) pada penelitian mereka yang menguji daya antibakteri gel ekstrak tanaman terhadap bakteri Staphylococcus aureus.

Hasil Uji Daya Hambat

\section{Gambar 1. Grafik Diameter Zona Hambat}

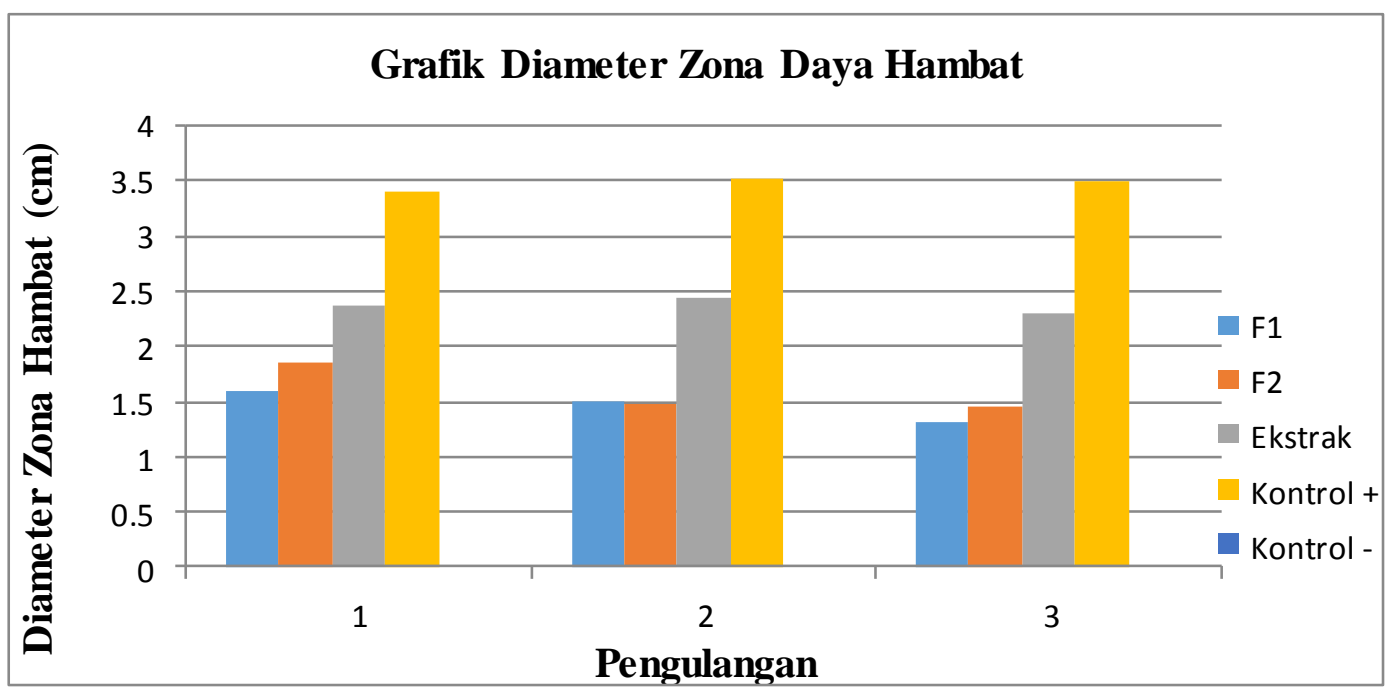

Dari data, dapat dilihat bahwa rata-rata diameter zona hambat bakteri formula $10 \%$ dan $20 \%$ adalah $1,50 \mathrm{~cm}$ dan $1,59 \mathrm{~cm}$ seperti pada gambar 1 . Data tersebut menunjukkan bahwa semakin tinggi konsentrasi formula maka semakin besar zona hambat yang dihasilkan. Hasil perbandingan pada kontrol negatif memiliki zona daya hambat 0 atau tidak memiliki daya hambat, sedangkan diameter zona hambat pada kontrol positif $3,47 \mathrm{~cm}$. Bila dibandingkan dengan kontrol positif maka efektifitas gel ekstral etanol bawang putih konsentrasi $10 \%$ sebesar $42 \%$ dari efektifitas kontrol positif, dan efektifitas gel ekstrak etanol bawang putih konsentrasi $20 \%$ sebesar $45 \%$ dibanding kontrol positif.
Data yang diperoleh pada tabel 4 hal.40, dianalisis menggunakan program komputer SPSS (Statistical Product and Service Solutio) 17.0 for windows p. Hasil analisa menunjukkan bahwa terdapat perbedaan yang signifikan antara rata-rata diameter zona hambat pada masing-masing kelompok dengan nilai $(\alpha<0,05)$ yang berarti bahwa terdapat perbedaan yang bermakna antara daya hambat gel ekstrak etanol bawang putih dengan gel Klindamisin gel dan basis gel terhadap bakteri Staphylococcus aureus.

Dari uji lanjutan Duncan, diketahui bahwa perbedaan antara ratarata diameter zona hambat gel ekstrak etanol bawang putih konsentrasi $10 \%$ dan 20\% tidak berbeda bermakna. Namun rata-rata diameter zona hambat 
gel ekstrak etanol konsentrasi $10 \%$ dan $20 \%$ berbeda bermakna dengan kelompok kontrol positif dan negatif, yang berarti gel ekstrak etanol bawang putih memiliki efektifitas yang berbeda bermakna dengan kontrol positif yaitu Klindamisin gel. Klindamisin mempunyai mekanisme membunuh bakteri dengan cara mencegah sintesis protein dari bakteri. Klindamisin merupakan antimikroba yang bersifat bakteriostatik maupun bakterisida (Putra et al.,2017)

Daya hambat gel ekstrak etanol bawang putih ini disebabkan karena kandungan kimia yang terkandung pada umbi bawang putih yaitu Alisin yang berfungsi sebagai penghambat berbagai pertumbuhan jamur dan bakteri. Senyawa Alisin terbentuk saat bawang mentah dipotong atau dihancurkan, pada saat itu bawang putih mengeluarkan enzim allinase dan yang akan mengkatalisis terbentuknya asam sulfenik dari sistein sulfoksida. Asam sulfenik akan saling bereaksi diantara mereka dan secara spontan membentuk senyawa thiosulfinate yang tidak stabil dan akhirnya membentuk alisin (Ichsan, 2009)

\section{UCAPAN TERIMAKASIH}

Ucapan terima kasih kepada reviewer Jurnal Riset Kefarmasian Indonesia dan Akademi Farmasi Proayoga Padang

\section{SIMPULAN}

Kesimpulan dari penelitian ini adalah :

1. Ekstrak etanol bawang putih dapat diformula menjadi sediaan gel berdasarkan hasil evaluasi gel yang dapat memenuhi syarat sebagai sediaan gel.

2. Gel ekstrak etanol bawang putih (Allium sativum L.) pada konsentrasi $10 \%$ dan $20 \%$ dapat menghambat pertumbuhan bakteri Staphylococcus aureus..

\section{DAFTAR PUSTAKA}

Afriyanti, R. N. (2015). Akne Vulgaris Pada Remaja. J Majority, 4(6), 102-109.

Anggraeni, D., \& Kamaluddin, H. M. T. (2018). Efektivitas Gel Ekstrak Air Bawang Putih ( Allium sativum . L ) Terhadap Kadar Tumor Necrotic Factor Alfa ( TNF- $\alpha$ ) Dan Diameter Ulkus Mulut Pada Tikus Putih Jantan Galur Wistar Ulkus mulut merupakan kondisi patologis yang ditandai dengan hilangnya jarin. Biomedical Journal of Indonesia, 4(3), 128-139.

Bayan, L., Koulivand, P. H., \& Gorji, A. (2014). Garlic: a review of potential therapeutic effects. Avicenna Journal of Phytomedicine, 4(1), 1-14.

Genaro, R. . (1990). Rhemingtons Pharmaceutical Science (8th ed.). Mack Printing Company.

Harahap, \& Marwali. (2000). Ilmu Penyakit Kulit. Hipokrates.

Ichsan, Z. (2009). Efek antibakteri ekstrak bawang putih (Allium sativum) terhadap pertumbuhan Streptococcus mutans secara in vitro. Universitas Sebelas Maret. Skripsi.

Iwalokun, B., Ogunledun, A., Ogbolu, D., Bamiro, S., \& Omojola, J. 
(2004). In Vitro Antimicrobial Properties of Aqueous Garlic Extract Against MultidrugResistant Bacteria and Candida Species from Nigeria. Journal of Medicinal Food, 7(3), 327-334. https://doi.org/10.1089/109662004 1938669

Les, L. H., Isnaeni, \& Soeratri, W. (2017). Aktivitas Antibakteri dan Stabilitas Sediaan Gel Minyak Atsiri Daun Jeruk Purut (Citrus hystrix folium). Jurnal Farmasi Dan Ilmu Kefarmasian Indoensia, 4(2), 67-73.

Myles, I., \& Datta, S. (2012). Staphylococcus aureus: an introduction. NIH Public Access, 34(2), 1-6. https://doi.org/10.1007/s00281-

011-0301-9

Ningsih, W., Firmansyah, \& Anggraini, S. (2016). Ekstrak Etanol Daun Kembang Bulan. Jurnal Ilmiah Farmasi, 2, 79-85.

Pelen, S., Wullur, A., \& Citraningtyas, G. (2016). Formulasi Sediaan Gel Antijerawat Minyak Atsiri Kulit Batang akyu Manis (Cinnamomum burmanii) Dan Uji Aktivitas Terhadap Bakteri Staphylococcus aureus. Pharmacon, 5(4), 136-144.

Prihandani, S. S., Poeloengan, M., \& Noor, S. M. (2015). Uji Daya
Antibakteri Bawang Putih ( Allium sativum L .) Terhadap Bakteri Staphylococcus aureus , Escherichia coli , Salmonella typhimurium DAN Pseudomonas aeruginosa dalam Meningkatkan Keamanan Pangan. Informatika Pertanian, 24(1), 53-58.

Putra, R.E.D., Homenta, H. dan Wowor, V.N.S. 2017. Uji daya hambat perasan jeruk purut Citrus Hytrix terhadap bakteri Staphylocuccus aureus secara in vitro. Jurnal Ilmiah Farmasi. 6(1):65-66.

Ross, Z. M., Gara, E. A. O., Hill, D. J., \& Sleightholme, H. V. (2001). Antimicrobial Properties of Garlic Oil against Human Enteric Bacteria : Evaluation of Methodologies and Comparisons with Garlic Oil Sulfides and Garlic Powder. Applied and Enviromental Microbiology, 67(1), 475-480. https://doi.org/10.1128/AEM.67.1. 475

Salima, J. (2015). Antibacterial Activity of Garlic ( Allium sativum 1 .). $J$ Majority, 4(2), 30-39.

Sampelan, M., Pangemanan, D., \& Kundre, R. (2017). Hubungan Timbulnya Acne Vulgaris Dengan Tingkat Kecemasan Pada Remaja di SMP N 1 Likupang Timur. EJournal Keperawatan, 5(1), 1-8. 